\title{
Between ecological convictions and practical considerations - profiles and motivations of residents in car-free housing developments in Germany and Switzerland
}

\author{
Daniel Baehler and Patrick Rérat \\ Institute of Geography and Sustainability, University of Lausanne, Lausanne, Switzerland \\ Correspondence: Daniel Baehler (daniel.baehler@unil.ch)
}

Received: 23 April 2019 - Revised: 13 May 2020 - Accepted: 23 May 2020 - Published: 22 June 2020

\begin{abstract}
Automobility still dominates transport and space in most European cities. However, more and more initiatives are being taken to encourage a transition towards low-carbon mobility. One of these is car-free housing, where residents commit to living without a private car. This paper addresses their profiles and motivations based on a questionnaire survey $(N=571)$ and interviews $(N=50)$ in nine housing developments in Germany and Switzerland. Residents are characterised by an overrepresentation of families and people with a high level of education, two population groups that are usually more motorised than average. Their motivations and long-term commitment to living car-free can be explained by not only practical reasons (e.g. availability of alternative modes) but also ecological awareness and social values (as shown by the importance of cooperative housing). This paper sheds light on these urban laboratories where the principles of a post-car system are implemented.
\end{abstract}

\section{Introduction}

European urban areas are usually dominated by cars. But in some cities, there are "laboratories" where residents have decided to live without owning a car. Their choice is significant in a world torn between two facts. On the one hand, we still live in a very car-centred society (Jeekel, 2013), based on the "system of automobility" (Urry, 2004). This notion highlights that the car is more than just a vehicle: it is a sociotechnical system and an assemblage of technologies, regulations and infrastructures as well as planning policies, various markets, practices, meanings and symbols (Urry, 2004; Dennis and Urry, 2009). On the other hand, the negative effects of the car (energy consumption, air pollution, emissions of greenhouse gases, etc.) have urged some local governments, NGOs and inhabitants to initiate the transition towards low-carbon mobility (Givoni and Banister, 2013).

Given these challenges, Dennis and Urry (2009) proposed the design and implementation of a "new post-car system". Such a system would provide the flexibility, comfort and secure personal mobility of the car but in a low-energy, low- carbon world. They identify eight ways to transform the system of automobility. Four technological developments (new fuel systems, new materials, smart vehicles and digitisation) address the car, while four organisational transformations (de-privatising vehicles, new transport policies, new living, work and leisure practices, and disruptive innovation) target the way mobility is organised. Car-free housing residents may be regarded as having decided to quit or not to enter the system of automobility by deciding not to own a private car (although they may use shared cars now and then). In a transition perspective, these developments can be analysed as "urban laboratories" or "real-world labs" used in transdisciplinary research to generate knowledge on more sustainable living (Parodi et al., 2017).

Various weak signals of a mobility transition, or at least of calling the car into question, are observed. Young adults seem less car-oriented, obtain their driver's licence later and buy fewer cars (Kuhnimhof et al., 2013; Rérat, 2018), and "peak car", or a maximum in car travel per capita, may already have been reached (Goodwin and Van Dender, 2013). Several European cities, such as Madrid and Oslo, have 
started to ban cars from their centres (Nieuwenhuijsen and Khreis, 2016); in addition to such top-down measures, there is also a growing number of bottom-up initiatives for car-free areas in existing urban neighbourhoods (Ortegon-Sanchez et al., 2017).

Car-free housing developments partake of this trend, having emerged in western Europe at the end of the 20th century. Residents commit to living without a private car, which makes them an interesting population to study as their decision cannot be easily reversed (to live car-free is generally part of the tenancy or mortgage agreement). For sustainability policies as well as transition initiatives, it is important to understand why these residents have left (or never entered) the "system of automobility" as well as who they are. Surprisingly, little is known about them in the literature.

The aim of this paper is to address the profile, the housing choice and the motivations for living car-free of the residents in nine housing developments in Germany and Switzerland. A literature review presents the research on car-free households as well as the few studies on car-free housing developments. The case studies and the methodology are then presented. The empirical section discusses the households' profiles and motivations, and the conclusion summarises the main messages in respect of the transition to a post-car system.

\section{Literature review}

This section first presents existing evidence on car-free households and their motivations in general and, second, focuses on those living in car-free housing developments. There is little research specifically on households living without a car, but the numerous studies on car ownership tend to include findings on carless households (Haefeli and Bieri, 2008:6; Preisendörfer and Rinn, 2003:27). While in recent years there has been a growing interest in carless households (Brown, 2017; Deleuil et al., 2017; Kühne et al., 2018; Lagrell et al., 2018; Sattlegger and Rau, 2016; Villeneuve, 2017), research on car-free housing is still lacking and is addressed by few if any recent scientific studies (Melia, 2009; Ornetzeder et al., 2008; Scheurer, 2001).

\subsection{Car-free households}

With the wide diffusion of the car after the Second World War, the number of car-owning households increased in the Western world to the point that owning a car became the norm (Dennis and Urry, 2009). In many countries, this led to "car dependence", creating social exclusion for people who could not access a car for financial or physical reasons (Dupuy, 2011), or to "forced car ownership" and "transport poverty" for households with limited financial resources (Mattioli, 2017; Mattioli et al., 2017).
Analyses of the profiles of car-free households based on statistical records show that, in general, three types of characteristics influence car ownership (Haefeli and Bieri, 2008; Kühne et al., 2018; Mitra and Saphores, 2017; Preisendörfer and Rinn, 2003). First, the profile of the household plays a role: household size, level of income and the presence of children correlate negatively with the likelihood of being car-free. Second, the profile of the individual plays a role. Women are more often car-free, while individuals who are employed and/or have a high level of education level are more likely to own a car. In terms of age, two groups have a higher likelihood of being car-free: young adults after leaving their parents' home and elderly people who have never owned a car or cannot drive anymore for health reasons. Finally, the residential context and transport infrastructures also influence car ownership. With increasing size and density of the place of residence, the proportion of car-free households grows. Car-related costs are also positively correlated with car-free households, while the opposite is seen with regard to public transport costs. Parking space supply has been found to have a significant positive effect on car ownership (Guo, 2013).

The three most important factors in explaining the absence of a car are household size, level of income and type of residential area (size and density; Haefeli and Bieri, 2008; Preisendörfer and Rinn, 2003). However, a growing number of households with profiles contrary to what would be expected in terms of life course and socio-economic status live voluntarily car-free. For example, although entering into parenthood still constitutes one of the life events most likely to lead to the purchase of a car (Clark et al., 2016; Oakil et al., 2016), studies in Vancouver (Canada) and Gothenburg (Sweden) show that some families are choosing to live without one (Lagrell et al., 2018; McLaren, 2016). In Switzerland, a study based on national statistics found that the proportion of young urban residents with high education and income levels (who could therefore afford a car) living car-free doubled between 1994 and 2010 to reach $27 \%$ of car-free households (Haefeli and Arnold, 2015).

\subsection{Motivations for living car-free}

In housing choice research, motivation represents one of three usual angles of analysis, the others being residential satisfaction and aspirations (Rérat, 2016). Some scholars have suggested that too much importance is given to attitudes, behaviours and choices in the field of sustainable transition and too much focus placed on individual agency and on minimising the role of context and "the rules of the game" (Shove, 2010). However, this critique is addressed primarily to the analysis of dominant or established practices, and it is nevertheless crucial to understand why some households adopt a specific way of living which, in the case of car-free housing, is still a niche phenomenon and calls into question the dominant mobility system. 
Evidence on the motivations of car-free households is restricted, partly because the prevalent quantitative research uses secondary data. But some mobility surveys address the reasons for living car-free, for example in Germany or California (Kühne et al., 2018). While in both places, about $30 \%$ of car-free households mention the high costs of buying or maintaining a car as the main reason for living car-free, $18 \%$ of the German and $8 \%$ of the Californian households prioritise age or health reasons. The differences are more significant for what can be considered voluntarily carless households: in Germany $28 \%$ do not need a car and $11 \%$ highlight "deliberate abstinence", whilst in California, $11 \%$ "can do what they need and want to without a car" and $4 \%$ are concerned about the impact on the environment (Caltrans, 2013; infas, 2018). An older study on carless households' motivations in Great Britain shows similar results: $32 \%$ chose not to have a car due to the costs involved, $31 \%$ because they had no need for one, $19 \%$ due to health or other physical difficulties, and $4 \%$ for environmental reasons (Aston and Budd, 2006).

Some early qualitative studies in Germany and Switzerland found similar motivations (Müller and Romann, 1999; Preisendörfer and Rinn, 2003; Reutter and Reutter, 1996). In addition, they found that the quality of alternative modes, particularly of public transport, was important, as well as a preference to spend money on things other than a car. Recent qualitative studies confirm that living car-free is often a combination of choice and constraints and highlight the need to change existing social norms regarding car ownership (Lagrell et al., 2018; Sattlegger and Rau, 2016; Villeneuve, 2017).

Finally, the role of the environment is nuanced. On the one hand, it appears as a rather important motivation when specifically mentioned in surveys. On the other hand, it is found to be much less important when respondents are asked to state spontaneously why they do not own a car (Preisendörfer and Rinn, 2003). Overall, the importance of ecological convictions is not conclusive (Brown, 2017; Deleuil et al., 2017), except in the case of particular groups living carfree by choice (Melia, 2009), such as residents of car-free housing developments (Ernst, 2008; Foletta and Henderson, 2016). Research shows that underlying ecological values do not always lead to sustainable practices (Ilstedt et al., 2017), notably in terms of travelling by plane (Prillwitz and Barr, 2011). While ecological motivations may not always be sufficient to cause people to adopt alternative forms of mobility, they can legitimate them: "If the relationship is traditionally thought through the influence of values on practices, this could be reversed as sustainable mobility practices also contribute to the construction of ecological values" (VincentGeslin, 2014:113). Therefore, it is necessary to go beyond traditional demographic and socio-economic variables and to explicitly address values defined as "desirable, transsituational goals, varying in importance, that serve as guiding principles in people's lives" (Schwartz, 1996:2). Values also link to lifestyles or social milieu approaches, going beyond traditional socio-demographic and socio-economic variables to explain differences between population groups (Rössel and Otte, 2011).

\subsection{Households living in car-free housing developments}

After 1945, western countries transformed into car-centred societies and parking was added to housing constructions as on-street parking was no longer sufficient. The first critical voices appeared in the 1960s with, for example, Jane Jacobs in the USA or the Buchanan report in the UK, but it was only towards the end of the so-called car century that the negative effects of automobility led to a different view of the car in cities. Car-free housing as defined here emerged in the 1990s in Germany, in the context of a sociological project on carfree households at the University of Bremen (Burwitz et al., 1992). The first development was built in Bremen (Grünenstraße) in 1995 (Scheurer, 2001), and several others followed in Europe, including in Switzerland in 2011.

Scientific research developed in parallel, but following evaluation of the first projects, only a few studies have addressed car-free housing. In what was probably the first study, Scheurer (2001) looked at nine eco-neighbourhoods, including five car-free or car-reduced projects, where carreduced means that there is less parking than demanded by planning and construction laws, so only a proportion of the residents (often about $20 \%$ to $30 \%$ ) can own a private car if they buy or rent a parking space. Scheurer focused on the planning and design of such urban developments and presented some early insights into the residents, including an overrepresentation of families. This was confirmed by other evaluations (grey literature) of car-free housing in Vienna, Hamburg and Munich, which reported higher proportions of highly educated residents and nearly no foreign citizens (Baier et al., 2004; Ernst, 2008; Moser and Stocker, 2008). The residential motivations of car-free housing residents are based more on the characteristics of the development (such as living in a community or ecological aspects such as an energy-efficient construction) than on those of the home itself. Car-freeness in itself is a motivation for only a few residents, whereas mobility-related aspects (e.g. a cyclist- and pedestrian-friendly environment or access to public transport) are central (Ernst, 2008; Moser and Stocker, 2008; Ornetzeder et al., 2008; Scheurer, 2001). This applies also to urban middle-class households moving to new developments (Jarass and Heinrichs, 2014; Rérat et al., 2013; Rérat and Lees, 2011). It links to the fact that a certain "hosting potential of a territory" (Kaufmann, 2012) is needed for car-free living. This concept highlights the importance of the spatial context: proximity as well as connections (by public transport or cycling paths mainly) to places of everyday life are necessary for car-free housing.

While the number of car-free housing developments is growing, no recent scientific studies exist, and the grey lit- 
erature focuses on specific projects and does not provide a comparative overview. We therefore have only very limited knowledge of the profiles and motivations of car-free housing residents, and hence there is an important research gap that needs to be filled in order to understand this laboratory of sustainable mobility.

\section{Research questions, case studies and methodology}

This paper answers two questions: who are the residents of car-free housing developments, and what are their motivations for living car-free and for moving to a car-free housing development? Car-free housing developments are defined as new-build estates where residents commit to living without a private car and thus without parking except for visitors, services, etc. Residents generally sign an appendix to their tenancy or mortgage agreement which includes the commitment not to own (or at least park) a car within the development and/or the surrounding neighbourhood.

To analyse the profiles and motivations of the residents of car-free housing developments, nine cases were studied in Switzerland (five) and Germany (four; Table 1). Two of them, Giesserei and Stellwerk60, are actually car-reduced (onefifth of the residents can get a parking space for a private car), but this paper only includes car-free residents. These developments are diverse in terms of size (from 20 to 426 units), context (location within the city and in cities of different sizes, mobility supply) and type of resident (renters, owners, cooperative members). Three developments are completely, and two partially, cooperative housing projects. This represents an alternative to renting and ownership that allows residents to keep some control over their housing and generally to live at a lower cost, as no investor is involved ${ }^{1}$. Results are presented in an aggregated way unless significant differences are observed between projects.

Both countries where the car-free housing projects are located are still largely car-centred, with above-average motorisation rates: in 2016, there were 555 cars per 1000 inhabitants in Germany and 537 in Switzerland; to compare, the average in the EU-28 in the same year was 510 (Eurostat, 2018). Moreover, in Germany, the presence of car manufacturers plays an important economic and political role. The share of car-free households is nonetheless increasing gradually, from $18 \%$ in 2008 to $22 \%$ in 2017 in Germany and from $19 \%$ in 2005 to $22 \%$ in 2015 in Switzerland, which is mainly due to changes in the biggest cities. In Bern, for example, $57 \%$ of households have no private car; in Zurich $53 \%$; in Berlin 51\%; and in Hamburg $43 \%$ (infas, 2018; OFS/ARE, 2017). Both countries also have a relatively highly developed

\footnotetext{
${ }^{1}$ Residents are members of the housing cooperative and thus buy shares. Cooperatives normally include self-management and the participation of residents in the planning process.
}

public transport network as well as cycling and walking infrastructures in many cities.

A mixed-method approach was adopted in order to gain an overview of the residents and a better understanding of their choices and practices. We used a two-phase "explanatory design" (Creswell and Plano Clark, 2007), in which qualitative data (interviews) help to explain or build upon initial quantitative results (survey). Both the survey and the interviews addressed the motivations for car-free living and residential choice and the residents' profiles as well as questions related to former places of residence and motorisation of their household before (for details, see Baehler, 2019).

A self-administered paper questionnaire was distributed to all 1244 households in the nine developments in October 2016, and a reminder was sent 2 weeks later. The response rate was $46 \%$ overall, ranging from $28 \%$ to $80 \%$ in each development (Table 1). The higher response rates recorded in cooperative housing were considered in the analysis, but the results still reflect the diversity of residents in all case studies. For practical reasons, the survey was addressed to the household and one member was asked to answer it, although most questions referred to the whole household. Similarly, most interviews were conducted with only one person but addressing the whole household. The relevance of this approach is supported by previous studies, which have shown that household heads consider their whole household and not only their personal situation in answering a survey (Bookwalter et al., 2006).

In 2017, interviews with 50 households in six housing developments were conducted (the two car-reduced developments and the very small project in Biel were left out). Interviewees were recruited from among respondents who left their address in the questionnaire and included a diversity of profiles in terms of household types, age and tenure status (tenants, owners and cooperative members). They reflect the characteristics of the overall population; only the interviewees' average age was higher than in the survey. To analyse the interviews, a "structured qualitative content analysis" (Kuckartz, 2016; Schreier, 2014) was conducted; i.e. the qualitative material was summarised into thematic categories (codes). These codes are not only deductive (relying on theory) but also inductive (emerging from the empirical material). Adopting a mixed-method approach may imply that the presentation of both methods is limited. However, the advantages of combining a quantitative overview with a qualitative deepening outweigh this limitation.

\section{Results}

This section presents and discusses the results of the analysis of both the questionnaire survey and the interviews. First, the profiles and values of the residents, then the reasons for living car-free and, finally, the housing choice motivations are addressed. 
Table 1. Characteristics of the car-free housing developments and the municipalities they are located in (data from 2017; sources are, for Switzerland, the Federal Statistical Office and, for Germany, the Statistisches Bundesamt (Destatis) and Kraftfahrt-Bundesamt).

\begin{tabular}{|c|c|c|c|c|c|c|c|c|c|}
\hline Name & $\begin{array}{l}\text { Municipality } \\
\left(\text { country }^{\mathrm{a}}\right)\end{array}$ & $\begin{array}{r}\text { Population } \\
\text { of the } \\
\text { municipality }\end{array}$ & $\begin{array}{r}\text { Motorisation } \\
\text { (cars per } 1000 \\
\text { inhabitants) }\end{array}$ & $\begin{array}{l}\text { Location } \\
\text { (and distance } \\
\text { to the city } \\
\text { centre) }\end{array}$ & $\begin{array}{l}\text { Type of } \\
\text { residents }\end{array}$ & $\begin{array}{c}\text { Year of } \\
\text { completion }\end{array}$ & $\begin{array}{r}\text { Number of } \\
\text { dwellings }\end{array}$ & $\begin{array}{l}\text { Response } \\
\text { rate of } \\
\text { the survey }\end{array}$ & $\begin{array}{l}\text { Households } \\
\text { interviewed }\end{array}$ \\
\hline Burgunder & $\operatorname{Bern}(\mathrm{CH})$ & 133798 & 381 & $\begin{array}{l}\text { Outskirts } \\
\text { of the city } \\
(3.5 \mathrm{~km})\end{array}$ & Renters & 2011 & 80 & $68 \%$ & 7 \\
\hline FAB-A & $\begin{array}{l}\text { Biel/Bienne } \\
(\mathrm{CH})\end{array}$ & 54640 & 390 & $\begin{array}{l}\text { Central } \\
\text { urban } \\
\text { district } \\
(0.5 \mathrm{~km})\end{array}$ & $\begin{array}{l}\text { Cooperative } \\
\text { members }\end{array}$ & 2014 & 20 & $80 \%$ & \\
\hline Giesserei $^{\mathrm{c}}$ & $\begin{array}{l}\text { Winterthur } \\
\text { (CH) }\end{array}$ & 110912 & 405 & $\begin{array}{l}\text { Outskirts } \\
\text { of the city } \\
(3 \mathrm{~km})\end{array}$ & $\begin{array}{l}\text { Cooperative } \\
\text { members }\end{array}$ & 2013 & 145 & $48 \%$ & \\
\hline Oberfeld & $\begin{array}{l}\text { Ostermundigen, } \\
\text { Bern }(\mathrm{CH})\end{array}$ & 17546 & 401 & $\begin{array}{l}\text { Suburban } \\
\text { municipality } \\
(4.5 \mathrm{~km})\end{array}$ & $\begin{array}{l}\text { Cooperative } \\
\text { members }\end{array}$ & 2014 & 94 & $78 \%$ & 8 \\
\hline Sihlbogen & Zurich $(\mathrm{CH})$ & 409241 & 343 & $\begin{array}{l}\text { Outskirts } \\
\text { of the city } \\
(4.5 \mathrm{~km})\end{array}$ & Renters & 2013 & 140 & $36 \%$ & 5 \\
\hline $\begin{array}{l}\text { Klein } \\
\text { Borstel }\end{array}$ & $\begin{array}{l}\text { Hamburg- } \\
\text { Ohlsdorf } \\
\text { (DE) }\end{array}$ & 1810438 & 426 & $\begin{array}{l}\text { Outskirts } \\
\text { of the city } \\
(10 \mathrm{~km})\end{array}$ & $\begin{array}{l}\text { Owners, } \\
\text { cooperative } \\
\text { members }\end{array}$ & 2008 & 62 & $66 \%$ & 9 \\
\hline $\begin{array}{l}\text { Saarland- } \\
\text { straße }\end{array}$ & $\begin{array}{l}\text { Hamburg- } \\
\text { Barmbek } \\
\text { (DE) }\end{array}$ & 1810438 & 426 & $\begin{array}{l}\text { Central } \\
\text { urban } \\
\text { district } \\
(4 \mathrm{~km})\end{array}$ & $\begin{array}{l}\text { Renters, } \\
\text { owners, } \\
\text { cooperative } \\
\text { members }\end{array}$ & 2000 & 141 & $48 \%$ & 12 \\
\hline Stellwerk60 ${ }^{\mathrm{d}}$ & $\begin{array}{l}\text { Cologne- } \\
\text { Nippes (DE) }\end{array}$ & 1075935 & 437 & $\begin{array}{l}\text { Central } \\
\text { urban } \\
\text { district } \\
(2.5 \mathrm{~km})\end{array}$ & $\begin{array}{l}\text { Renters, } \\
\text { owners }\end{array}$ & 2006 & 426 & $38 \%$ & \\
\hline Weißenburg & $\begin{array}{l}\text { Münster, } \\
\text { Westphalia } \\
\text { (DE) }\end{array}$ & 311846 & 452 & $\begin{array}{l}\text { Central } \\
\text { urban } \\
\text { district } \\
(2 \mathrm{~km})\end{array}$ & Renters & 2001 & 136 & $28 \%$ & 9 \\
\hline Total & & & & & & & 1244 & $46 \%$ & 50 \\
\hline
\end{tabular}

${ }^{a} \mathrm{CH}$ denotes Switzerland, and DE denotes Germany. ${ }^{\mathrm{b}}$ Note that the Swiss municipalities are the centres of bigger agglomerations (except Ostermundigen, a suburban municipality). For example, Bern is at the core of an urban region with about 400000 residents. Zurich is the biggest city in Switzerland, Bern the 5th, Winterthur the 6th and Biel/Bienne the 10th. ${ }^{c}$ Giesserei is a car-reduced development, providing parking for about $20 \%$ of the dwellings. ${ }^{\mathrm{d}}$ Stellwerk60 is a car-reduced development, providing parking for $18 \%$ of the dwellings.

\subsection{Profiles and values of the residents - a very particular car-free population}

Who are the residents living in the car-free developments? Nearly half of the households are families ( $41 \%$ are couples with at least one child; $7 \%$ are single-parent families). Onethird are persons living alone, $17 \%$ couples without children and $3 \%$ flat-shares. The proportion of families is even higher in three of the developments (Table 2) and, except in Giesserei, is significantly higher than the urban average of $20 \%$ to $30 \%$ in the same cities. The overrepresentation of families is also striking compared to car-free households in general. The age distribution is in line with the household type: about one-third of the residents are aged below 20 years old, less than $5 \%$ are between 20 and 29 , about $40 \%$ are 30 to 50 years old, and only a few are 80 and older. Few residents in each development are foreign citizens, except in Sihlbogen $(38 \%)$; this stands in contrast with the cities they are located in $(25 \%$ to $33 \%$ in the Swiss cases and $7 \%$ to $16 \%$ in the German ones; Federal Statistical Office, 2016; Statistische Ämter des Bundes und der Länder, 2014). The relative absence of foreign citizens may be explained by the kind of housing development: living in a cooperative requires some knowledge about the region and the housing market, as the developments are often not advertised on conventional platforms. The majority of the inhabitants had already lived in the same city or urban region before (between $52 \%$ and $98 \%)$. 
Table 2. Socio-demographic characteristics of the residents.

\begin{tabular}{|c|c|c|c|c|c|c|c|c|c|c|}
\hline & Burgunder & FAB-A & Giesserei & Oberfeld & Sihlbogen & Klein Borstel & Saarlandstr. & Stellwerk60 & Weißenburg & Total \\
\hline \multicolumn{11}{|c|}{ Type of household $(N=486)$} \\
\hline Persons living alone & $32 \%$ & $6 \%$ & $39 \%$ & $38 \%$ & $22 \%$ & $22 \%$ & $43 \%$ & $35 \%$ & $18 \%$ & $32 \%$ \\
\hline Childless couples & $15 \%$ & $13 \%$ & $31 \%$ & $13 \%$ & $35 \%$ & $2 \%$ & $19 \%$ & $13 \%$ & $12 \%$ & $17 \%$ \\
\hline Couples with child(ren) & $50 \%$ & $69 \%$ & $22 \%$ & $42 \%$ & $35 \%$ & $66 \%$ & $23 \%$ & $46 \%$ & $44 \%$ & $41 \%$ \\
\hline Single-parent families & $2 \%$ & $13 \%$ & $6 \%$ & $6 \%$ & $0 \%$ & $10 \%$ & $14 \%$ & $4 \%$ & $21 \%$ & $7 \%$ \\
\hline Flat-shares & $2 \%$ & $0 \%$ & $2 \%$ & $3 \%$ & $8 \%$ & $0 \%$ & $2 \%$ & $2 \%$ & $6 \%$ & $3 \%$ \\
\hline Total & $100 \%$ & $100 \%$ & $100 \%$ & $100 \%$ & $100 \%$ & $100 \%$ & $100 \%$ & $100 \%$ & $100 \%$ & $100 \%$ \\
\hline \multicolumn{11}{|l|}{ Age (years; $N=1151$ ) } \\
\hline $0-9$ & $35 \%$ & $29 \%$ & $12 \%$ & $24 \%$ & $19 \%$ & $16 \%$ & $6 \%$ & $22 \%$ & $25 \%$ & $21 \%$ \\
\hline $10-19$ & $0 \%$ & $10 \%$ & $6 \%$ & $12 \%$ & $2 \%$ & $27 \%$ & $20 \%$ & $13 \%$ & $13 \%$ & $12 \%$ \\
\hline 20-29 & $2 \%$ & $2 \%$ & $4 \%$ & $3 \%$ & $13 \%$ & $1 \%$ & $7 \%$ & $2 \%$ & $10 \%$ & $4 \%$ \\
\hline $30-39$ & $35 \%$ & $18 \%$ & $13 \%$ & $21 \%$ & $43 \%$ & $2 \%$ & $9 \%$ & $14 \%$ & $10 \%$ & $18 \%$ \\
\hline $40-49$ & $18 \%$ & $31 \%$ & $14 \%$ & $15 \%$ & $13 \%$ & $27 \%$ & $9 \%$ & $28 \%$ & $15 \%$ & $19 \%$ \\
\hline $50-59$ & $6 \%$ & $8 \%$ & $14 \%$ & $10 \%$ & $5 \%$ & $21 \%$ & $31 \%$ & $12 \%$ & $20 \%$ & $14 \%$ \\
\hline $60-69$ & $4 \%$ & $0 \%$ & $16 \%$ & $7 \%$ & $3 \%$ & $5 \%$ & $13 \%$ & $5 \%$ & $7 \%$ & $7 \%$ \\
\hline 70-79 & $2 \%$ & $2 \%$ & $16 \%$ & $6 \%$ & $2 \%$ & $2 \%$ & $5 \%$ & $2 \%$ & $0 \%$ & $4 \%$ \\
\hline $80+$ & $0 \%$ & $0 \%$ & $3 \%$ & $1 \%$ & $1 \%$ & $0 \%$ & $1 \%$ & $1 \%$ & $0 \%$ & $1 \%$ \\
\hline Total & $100 \%$ & $100 \%$ & $100 \%$ & $100 \%$ & $100 \%$ & $100 \%$ & $100 \%$ & $100 \%$ & $100 \%$ & $100 \%$ \\
\hline \multicolumn{11}{|l|}{ Nationality $(N=1148)$} \\
\hline Swiss & $93 \%$ & $92 \%$ & $92 \%$ & $92 \%$ & $62 \%$ & $0 \%$ & $0 \%$ & $2 \%$ & $0 \%$ & $44 \%$ \\
\hline German & $3 \%$ & $8 \%$ & $4 \%$ & $3 \%$ & $16 \%$ & $98 \%$ & $97 \%$ & $95 \%$ & $100 \%$ & $52 \%$ \\
\hline Other & $5 \%$ & $0 \%$ & $4 \%$ & $4 \%$ & $22 \%$ & $2 \%$ & $3 \%$ & $3 \%$ & $0 \%$ & $5 \%$ \\
\hline Total & $100 \%$ & $100 \%$ & $100 \%$ & $100 \%$ & $100 \%$ & $100 \%$ & $100 \%$ & $100 \%$ & $100 \%$ & $100 \%$ \\
\hline
\end{tabular}

In terms of socio-economic characteristics (Table 3), over $60 \%$ of the residents (aged 15 and older) hold a university degree. Their income level, as well as the fact that $84 \%$ have a driving licence, indicates that these residents could afford a car but have made an informed choice to live without one. It also emphasises the particularity of the car-free housing residents compared to car-free households and to the wider urban population, where at most one-third hold a university degree. Nevertheless, it has to be noted that all types of residents are present in car-free housing developments and that the overrepresentation of highly educated residents may be partly due to the fact that they more readily answer surveys. This overrepresentation is not explained by the housing costs, which are not above average (some German developments are even subsidised housing and thus inaccessible to households with high incomes). It may be easier for these persons to acquire the skills needed for living without a private car. In their situation, making this long-term decision can be considered a way of life and will not be perceived as a failure in a carcentred society.

The high proportion of cooperative members ( $40 \%$ overall, compared to $16 \%$ of owners and $44 \%$ of tenants) also demonstrates the particularity of the population. Living in a cooperative often includes a certain engagement and an openness to living more closely with others and sharing some amenities and activities. The residents' values were surveyed through an adaptation of those in the European Social Survey (Schwartz, 2001). The most important groups of basic human values for the residents (Table 4) are, by far, self- transcendence (values related to universalism and benevolence, including ecological and social aspects) and openness to change (values of hedonism and self-direction which are, in the main, more personal goals). The items with the highest importance are "equal treatment and opportunities for every person", "taking care of nature, protecting the environment", and "devoting myself to people close to me, being loyal to them". Values related to conservation and self-enhancement, however, have the smallest relevance, and the least important items are "being rich, having expensive things" and "always behaving properly, avoiding doing anything people would say is wrong".

An additional indication of strong social and ecological values are the residents' voting intentions. Overall, $86 \%$ would vote for left parties, ranging from $60 \%$ to $100 \%$ (Table 5). In comparison, up to $53 \%$ in Swiss cities (BFS, 2016) and $27 \%$ in their German counterparts (Der Bundeswahlleiter, 2017) have voted for the socialist and green parties (SP, Grüne and AL in Switzerland; Die Linke and Die Grünen in Germany). These important differences highlight that for most residents, living without a car and in cooperative housing also represent a political statement.

\subsection{Motivations of car-free living - between personal convictions and practical reasons}

As $94 \%$ of the survey respondents agreed to live deliberately without a private car (only in Sihlbogen was this significantly lower at $80 \%$ ), the results on motivations for car-free liv- 


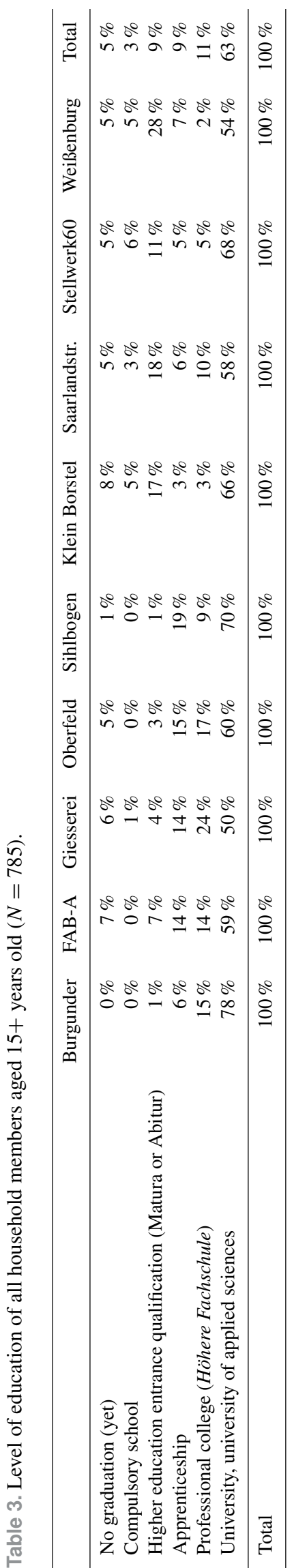

Table 4. Importance of basic human values for the residents, based on 21 single items $(N=452$ to 475$)$.

\begin{tabular}{llrr}
\hline Group of values & Value & $\begin{array}{r}\text { Very } \\
\text { important }\end{array}$ & Important \\
\hline \multirow{2}{*}{ Self-transcendence } & Universalism & $38 \%$ & $40 \%$ \\
& Benevolence & $26 \%$ & $42 \%$ \\
\hline \multirow{3}{*}{ Openness to change } & Self-direction & $32 \%$ & $36 \%$ \\
& Hedonism & $19 \%$ & $42 \%$ \\
& Stimulation & $8 \%$ & $23 \%$ \\
\hline \multirow{3}{*}{ Conservation } & Security & $7 \%$ & $16 \%$ \\
& Tradition & $4 \%$ & $12 \%$ \\
& Conformity & $3 \%$ & $12 \%$ \\
\hline \multirow{2}{*}{ Self-enhancement } & Achievement & $3 \%$ & $11 \%$ \\
& Power & $1 \%$ & $4 \%$ \\
\hline
\end{tabular}

ing provide general insights into the voluntary urban car-free population.

To address the challenges inherent in measuring the weight of environmental reasons (due to the fact that respondents give it a higher importance if asked about it specifically), the survey contained an open question on motivations, followed later in the questionnaire by a closed question based on the factors identified in the literature. Two types of important reasons emerged: practical aspects and personal convictions. The first type of motivation relates to utilitarian aspects, which are based on the (mobility) infrastructure and the residents' travel needs in their everyday life. Personal motivations are driven by values and convictions which explain the choice not to own a private car.

Interestingly, environmental reasons $(40 \%)$ are the motivation most often mentioned spontaneously. The absence of a need for a car follows just behind (39\%), along with the availability of alternative modes of mobility (35\%). About $20 \%$ of the respondents mention additional personal reasons or financial priorities other than spending money on a car, but very few mention affordability or age and health reasons. The closed question had six items and showed some small differences (Fig. 1). Whilst nearly all residents agree that they have no need for a car and have access to adequate alternatives, over $80 \%$ prefer to spend money on other things and $75 \%$ ticked environmental reasons. These results show the informed choices made by residents and are in line with the literature on car-free households, except in the case of environmental reasons.

The interviews enabled a better understanding of the reasons summarised in the survey and of their combinations. For practical reasons, it appears that there are individual and contextual motivations. Individual motivations include the absence of a need for a car, certain negative aspects of owning and driving a car (particularly in the city), and the idea of using and sharing rather than owning vehicles. Residents high- 
Table 5. Voting intentions of the residents $(N=444)$.

\begin{tabular}{|c|c|c|c|c|c|c|c|c|c|c|}
\hline & Burgunder & FAB-A & Giesserei & Oberfeld & Sihlbogen & Klein Borstel & Saarlandstr. & Stellwerk60 & Weißenburg & Total \\
\hline Left & $87 \%$ & $100 \%$ & $96 \%$ & $85 \%$ & $60 \%$ & $82 \%$ & $93 \%$ & $83 \%$ & $92 \%$ & $86 \%$ \\
\hline Centre-left & $12 \%$ & $0 \%$ & $2 \%$ & $12 \%$ & $14 \%$ & $10 \%$ & $6 \%$ & $6 \%$ & $0 \%$ & $8 \%$ \\
\hline Centre-right & $2 \%$ & $0 \%$ & $2 \%$ & $3 \%$ & $16 \%$ & $8 \%$ & $2 \%$ & $11 \%$ & $8 \%$ & $6 \%$ \\
\hline Right & $0 \%$ & $0 \%$ & $0 \%$ & $0 \%$ & $11 \%$ & $0 \%$ & $0 \%$ & $0 \%$ & $0 \%$ & $1 \%$ \\
\hline Total & $100 \%$ & $100 \%$ & $100 \%$ & $100 \%$ & $100 \%$ & $100 \%$ & $100 \%$ & $100 \%$ & $100 \%$ & $100 \%$ \\
\hline
\end{tabular}

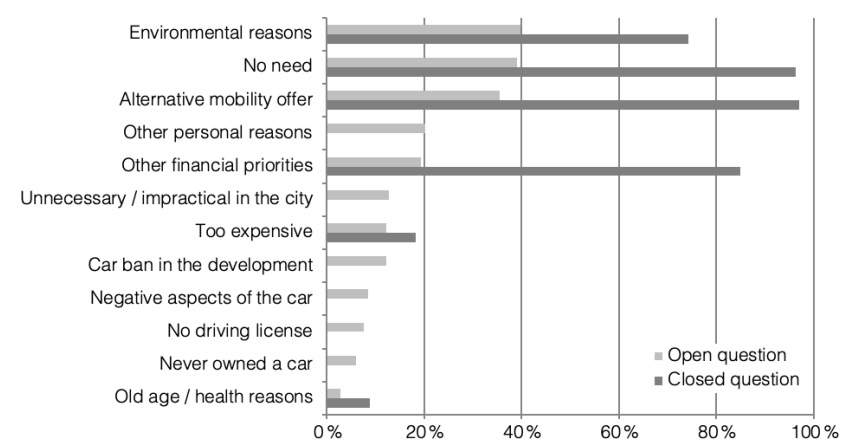

Figure 1. Comparison between the motivations for car-free living in the closed question ( $N=468$ to 481 ) and those mentioned spontaneously in the open question $(N=327)$.

light that they sometimes need a car but do not need to own one as they can rely on car sharing. They prefer to be car-free because it means that they do not need to care for a car and that they can use the appropriate type of car for a particular need, e.g. a van for transporting furniture. Finally, a car-free habit was also mentioned by some residents, who state that it is just "normal" for them to live without a private car:

This is natural for me, I have been living now really for nearly 30 years without a car, at some point this is like brushing your teeth. (Woman living alone, 70 years old, Saarlandstraße)

Contextual motivations include not only the availability of alternatives to a private car but also the fact that cities, especially the ones in which the respondents live, are adapted to car-free living:

Here in Münster you don't need it, you can get everywhere by bicycle and public transport, and if you really want to go further away, then we have [car sharing] or the train. (Woman living in a couple with children, 40 years old, Weißenburg)

Personal motivations to live car-free can be separated into convictions, preferences and a negative attitude towards cars. Convictions are mainly, but not exclusively, ecological and include for some interviewees the desire to be a "good example", i.e. to demonstrate that living without a private car is possible and to (try to) convince other people to do so:
I also think it is important to be a good example in this domain and to show, also to my children, relatives and friends, for example, that it is also possible, without restrictions. (Woman living in a couple with children, 40 years old, Burgunder)

Some residents prefer other transport modes to the car or see a car-free life as a freedom or a relief. Negative attitudes to the car can be of a general nature or related to cars in an urban context in particular:

There is no need for cars, especially in Switzerland, this is my attitude. (Man living in a couple with children, 40 years old, Burgunder)

I find that cars in big cities are also just not necessary, you can reach everything in the city by public transport and bicycle and on foot. (Woman living in a couple with children, 40 years old, Weißenburg)

Finally, financial reasons were also mentioned but mainly in the sense that respondents prefer to spend money on things other than a car.

The interviews also shed light on how reasons are combined. All respondents stated at least two different types of reasons. Four types of combination exist. For nearly half of the interviewees (23), personal reasons are predominant and practical reasons secondary, meaning that they have a strong desire to live car-free and therefore have organised their life in order to have no need for a car. For a second group (12), practical reasons are predominant and personal reasons secondary. They have no need for a car and do not want to own one in any case. Another group (11) highlights practical, personal and also financial reasons for living car-free. Finally, four households mention only practical and financial reasons for not owning a car; convictions or other personal reasons do not seem to play a role for them. This last group is present only in conventional housing developments, while the residents in the first group, who emphasise personal reasons, mainly live in cooperative housing projects.

The importance of personal reasons confirms the idea of a particularly engaged population that does not (only) live car-free because of personal comfort. At the same time, the results highlight that environmental convictions alone would probably not suffice for most residents, but practical reasons 


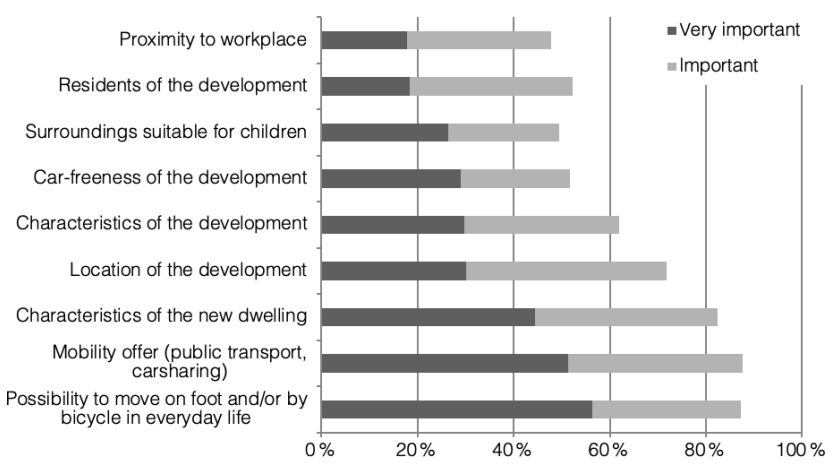

Figure 2. Importance of housing choice motivations $(N=466$ to 486 ).

come into play, too: the spatial context must satisfy residents' mobility needs through the provision of alternative modes as well as through the proximity to places of everyday life.

\subsection{Motivations of housing choice - the importance of accessibility and social aspects}

Why did households commit to living car-free by moving to a particular housing development? All nine motivations in the survey were rated important or very important by at least $48 \%$ of the residents (Fig. 2). Three reasons for housing choice even exceed $80 \%$, of which two are mobilityrelated (the possibility of getting around on foot and by bicycle and the mobility offer in general), and the third relates to the characteristics of the new dwelling (e.g. size, comfort, price). Just behind, in fourth position, is the location of the new development, also closely linked to mobility issues. The characteristics of the development (e.g. ecological construction, design, common rooms), the type of inhabitants and the car-freeness of the development are also mentioned by over $50 \%$ of respondents. The two remaining factors are just below this mark: proximity to the workplace and the suitability of the surroundings for children. These factors had the highest number of "not (at all) important" answers, as they do not concern all residents.

Comments in the questionnaires as well as in the interviews revealed supplementary housing choice motivations. First, the importance of the development's characteristics is highlighted. The cooperative nature of the development was a very strong residential motivation (in Giesserei, Klein Borstel, Oberfeld and Saarlandstraße), and related to this (in Burgunder as well), participation during the planning and construction period and self-administration after completion appeared equally important:

What fascinated me more was self-organisation and self-administration, that appealed to me. (Woman living alone, 70 years old, Saarlandstraße)

The whole concept of partial self-administration [including maintenance of the outdoor spaces or the right to propose new tenants when someone leaves], that was almost what appealed to us more than the car-freeness, $[\ldots]$ we found that was great, you can design the development together with the people, develop it further, contribute. (Man living in a couple with children, 40 years old, Burgunder)

In these more communitarian developments, shared or common rooms and spaces are also mentioned, as are the outdoor spaces, which many consider more attractive due to the absence of cars.

Closely related is another major motivation: community living. It was the most frequently mentioned aspect, both in the survey comments and in the interviews. This comprises the wish to live less anonymously and to share certain activities with neighbours, especially in the cases where future residents already knew each other and planned the project together:

I just think it's nice to live in a development where you know your neighbours from the start. (Man living alone, 60 years old, Saarlandstraße)

Here is united everything we have missed: form a small society, or community, where we support each other, pursue goals together. (Man living in a couple with children, 45 years old, Oberfeld)

This wish to live with like-minded neighbours who help each other is especially attractive not only to families (particularly those with a single parent) but also for persons (particularly the elderly) living alone, now or in the future. The importance of multigenerational living was also raised by some residents.

Accessibility proves to be much more important than a precise distance from the city centre, even if there seems to be a certain limit related to average cycling distances. Finally, personal convictions and the quality of life in car-free housing developments were mentioned. And as for reasons for living without a private car, there is always a combination in any housing choice, mostly between car-freeness and social aspects such as community living or co-housing and self-administration.

In the questionnaire, the concept of car-freeness appears as a less important motivation. The interviews enabled a better understanding of its role in the housing choice process. Five variants appeared: for some households, it is a key motivation; another group of households have a positive attitude towards it but were not initially looking for it; some respondents are indifferent to this aspect, and a few even accepted car-freeness in order to live in the housing development (because of other characteristics such as a collaborative housing project). Nearly half (23) of the interviewed households mentioned that they were already car-free before ( 15 others had not owned a car before but did not mention it in relation to residential motivations). 
To summarise, daily mobility is a crucial residential motivation, a finding in line with other similar studies on residents of new-build urban developments (Jarass and Heinrichs, 2014; Rérat et al., 2013; Rérat and Lees, 2011). It is not car-free housing in itself that is necessarily attractive but the specific alternative mobility it offers and accessibility it provides. Furthermore, for a large proportion of residents - mainly in the cooperatives - sustainability, social aspects such as community living, participation and selfadministration are as important as mobility-related characteristics and can even convince former car owners to move to a car-free development. The survey shows that $26 \%$ of the households gave up a car when moving in (between $15 \%$ and $42 \%$ per development). Therefore, the results show that "residential self-selection" - the choice of housing where the preferred transport modes can be used (Cao et al., 2009) plays a role but is not the only factor in explaining residents' housing choices.

\section{Conclusion}

This paper addresses the profiles and motivations of residents in nine car-free housing developments in Germany and Switzerland. Car-free housing projects are seen as urban laboratories in the frame of initiatives to implement a post-car system (Dennis and Urry, 2009). Thus, understanding who the residents are, why they moved to a car-free development and why they have decided to live without a private car in the long term brings crucial insights to the debate on mobility transition and on the potential of such projects.

The residents in the nine car-free developments are characterised by a high proportion of families and of people with a university degree (or equivalent). This stands in contrast with the literature on automobility, which shows that motorisation is correlated with the presence of children in the household and with the level of education (and income; Haefeli and Bieri, 2008; Kühne et al., 2018; Mitra and Saphores, 2017; Preisendörfer and Rinn, 2003). However, these observations are in line with other studies on similar housing projects (Baier et al., 2004; Ernst, 2008; Moser and Stocker, 2008; Scheurer, 2001), which show that car-free living may be attractive for population groups that are usually more motorised than average. Our study shows, however, a very specific profile in terms of values and voting intentions: residents are much more likely than the other citizens of their cities to vote for the left and to have altruistic values. Living car-free and in a car-free development is a way for these residents to translate their values into action.

Nearly all households state that they live deliberately without a private car and that this renouncement is not a sacrifice. Two main ranges of motivations appear, mostly in combination: practical reasons (no need for a car, availability of alternative mobility modes) and personal convictions (especially ecological ones). The motivations underlying housing choice are also driven by practical reasons (e.g. accessibility of the housing development), while social characteristics (community living or cooperative housing) are also important. Pragmatic reasons may explain why people choose to be carless, but environmental and social issues explain the long-term commitment that is only reversible by moving out of a car-free housing development. To summarise, motivations are a combination of willingness to live car-free and the feasibility of doing so, on a personal level and according to the social and spatial context. The characteristics of the context play an important role, based on its "hosting potential" (Kaufmann, 2012) to enable mobility without owning a private car through the accessibility of other modes of transport and the places of everyday life. In addition, residents of carfree housing developments perceive the quality of life to be higher without owning a car, not only when moving around the city but also in the residential environment where green spaces replace parking lots. Families seem to be attracted by the opportunity to combine urban living with an environment attractive for children to grow up in.

Nonetheless, some differences are observed between the nine developments. The difference between the car-free residents and the population of the city they are located in is much less valid for Sihlbogen, probably due to its rather common rental-housing aspects. Social and ecological motivations and values are more emphasised in the cooperatives, while in the other developments, practical motivations are more predominant. However, while the majority of carfree housing residents represents a particular population, it must not be forgotten that a diversity of households live in these projects (in terms of life course position, level of education, etc.). This means that car-free housing not only addresses urban citizens with strong ecological and social values and practices but also attracts former car owners: $26 \%$ of the households owned a car before moving in.

A key issue is to discuss if car-free housing could be generalised at a larger scale. On the one hand, the case studies have attracted a specific population in terms of values, political awareness, cultural capital and lifestyles. On the other hand, car-free living is the result of the conscious choice of population groups that are usually motorised (families and highly educated people). This shows that living without a private car may be not only possible but also desirable (as shown for example by the fact that practical aspects are at least as important as ecological and community-related motivations). It may also contribute to legitimate what is still a minority practice in respect of the dominant automobile system.

The results presented above also show the importance of further studies on car-free housing. They could address the residents' strategies to live car-free and compare their profiles and mobility practices with the inhabitants of the neighbouring areas and with other car-free households. This would provide insight into the potential of car-free housing developments in the context of the transition to a post-car sys- 
tem. Results regarding the social and spatial context indicate that a higher hosting potential of urban areas for alternative transportation modes to the car would make car-free living more attractive for a larger population. This would also require more studies not only at the scale of the housing developments but also in the larger urban and social context favouring car-free mobility (including restriction of car use in cities). In this sense, car-free housing developments represent laboratories on the way to living without private cars that could inspire the construction of new neighbourhoods and the transformation of existing urban areas.

In light of the negative impacts of the automobile system, car-free housing represents a promising strategy for the achievement of a post-car world, as it facilitates the use of alternative transport modes, addressing the place of residence where most residents' journeys start or end. Therefore, even if it is still a niche phenomenon, car-free housing has an important potential to contribute to the mobility transition and could therefore be supported and promoted by municipalities.

Data availability. Both the survey and the interviews were conducted under the condition of confidentiality. Therefore, data are not publicly accessible in order to protect the identity of the residents.

Author contributions. DB gathered, prepared and analysed the empirical material and drafted and finalised the article. DB and PR discussed the concept of the article and wrote the conclusion together. PR provided feedback and recommendations during the whole research process and on article drafts.

Competing interests. The authors declare that they have no conflict of interest.

Acknowledgements. The authors would like to thank the respondents of the survey questionnaire and the interviewees in the carfree housing developments as well as the reviewers of this paper.

Review statement. This paper was edited by Myriam HoussayHolzschuch and reviewed by four anonymous referees.

\section{References}

Aston, J. and Budd, T.: Attitudes to car use, DfT - Department for Transport, London, 2006.

Baehler, D.: Living in a car-free housing development. Motivations and mobility practices of residents in nine developments in Switzerland and Germany, PhD Thesis, Université de Lausanne, Lausanne, available at: https://serval.unil.ch/notice/serval: BIB_2053C99A97BC (last access: 11 May 2020), 2019.
Baier, R., Grunow, M., and Peter-Dosch, C.: Autofreies Wohnen - Begleituntersuchung zur autofreien Siedlung HamburgSaarlandstraße, Schlussbericht, BSV Büro für Stadt- und Verkehrsplanung, Dr.-Ing. Reinhold Baier GmbH, Aachen, 2004.

BFS: Nationalratswahlen 2015: Stärke der Parteien und Wahlbeteiligung nach Gemeinden, available at: https://www. bfs.admin.ch/bfs/de/home/statistiken/kataloge-datenbanken/ tabellen.assetdetail.317521.html (last access: 28 February 2018), 2016.

Bookwalter, J. T., Fuller, B. S., and Dalenberg, D. R.: Do Household Heads Speak for the Household? A Research Note, Soc. Indic. Res., 79, 405-419, https://doi.org/10.1007/s11205-005-4925-9, 2006.

Brown, A. E.: Car-less or car-free? Socioeconomic and mobility differences among zero-car households, Transp. Policy, 60, 152159, https://doi.org/10.1016/j.tranpol.2017.09.016, 2017.

Burwitz, H., Koch, H., and Badoni, T. K.: Leben ohne Auto?: neue Perspektiven für eine menschliche Stadt, Rowohlt, Reinbek bei Hamburg, 1992.

Caltrans: 2010-2012 California Household Travel Survey Final Report, California Department of Transportation, available at: http://www.dot.ca.gov/hq/tpp/offices/omsp/statewide_travel_ analysis/Files/CHTS_Final_Report_June_2013.pdf (last access: 27 March 2019), 2013.

Cao, X. (J.), Mokhtarian, P. L., and Handy, S. L.: Examining the Impacts of Residential Self-Selection on Travel Behaviour: A Focus on Empirical Findings, Transp. Rev., 29, 359-395, https://doi.org/10.1080/01441640802539195, 2009.

Clark, B., Chatterjee, K., and Melia, S.: Changes in level of household car ownership: the role of life events and spatial context, Transportation, 43, 565-599, https://doi.org/10.1007/s11116015-9589-y, 2016.

Creswell, J. W. and Plano Clark, V. L.: Designing and conducting mixed methods research, Sage Publ., Thousand Oaks, 2007.

Deleuil, J.-M., Barbey, E., and Sintès, A.: Le dévoiturage ou la ville sans (sa) voiture: mobilités plurielles, services numériques et vie de quartier, Flux, 108, 80-87, 2017.

Dennis, K. and Urry, J.: After the car, Polity, Cambridge, Malden, MA, 2009.

Der Bundeswahlleiter: Bundestagswahl 2017. Ergebnisse, available at: https://www.bundeswahlleiter.de/bundestagswahlen/2017/ ergebnisse.html (last access: 28 February 2018), 2017.

Dupuy, G.: Towards sustainable transport: the challenge of car dependence, John Libbey Eurotext, Esher, Surrey, 2011.

Ernst, M.: Autofrei Wohnen. Wir können's nur empfehlen! Ergebnisse der Bewohnerbefragung 2007, Wohnen ohne Auto, München, 2008.

Eurostat: Key figures on Europe - Statistics illustrated, European Union, Luxembourg, available at: https://ec.europa.eu/ eurostat/documents/3217494/9309359/KS-EI-18-001-EN-N. pdf/0b8d8b94-541d-4d0c-b6a4-31a1f9939a75 (last access: 22 April 2019), 2018.

Federal Statistical Office: Portraits of the communes, available at: https://www.bfs.admin.ch/bfs/en/home/statistiken/ regionalstatistik/regionale-portraets-kennzahlen/gemeinden/ gemeindeportraets.html (last access: 11 April 2019), 2016.

Foletta, N. and Henderson, J.: Low car(bon) communities?: inspiring car-free and car-lite urban futures, Routledge, Abingdon, Oxon, New York, 2016. 
Givoni, M. and Banister, D., Eds.: Moving towards low carbon mobility, Edward Elgar, Cheltenham, UK, Northampton, MA, 2013.

Goodwin, P. and Van Dender, K.: 'Peak Car' Themes and Issues, Transp. Rev., 33, 243-254, https://doi.org/10.1080/01441647.2013.804133, 2013.

Guo, Z.: Does residential parking supply affect household car ownership? The case of New York City, J. Transp. Geogr., 26, 18-28, https://doi.org/10.1016/j.jtrangeo.2012.08.006, 2013.

Haefeli, U. and Arnold, T.: Autofreie Lebensstile - Spezialauswertungen der Mikrozensen Verkehr 1994, 2000, 2005 und 2010 sowie der Haushaltsbudgeterhebung (HABE) 2009-2011, Interface Politikstudien Forschung Beratung, Luzern, 2015.

Haefeli, U. and Bieri, O.: Der autofreie Lebensstil. Spezialauswertungen der Mikrozensen Verkehr 1994, 2000 und 2005 sowie der Eidgenössischen Einkommens- und Verbrauchserhebungen 2003-2005, INTERFACE - Institut für Politikstudien, Luzern, 2008.

Ilstedt, S., Eriksson, E., and Hesselgren, M.: Sustainable lifestyles - how values affect sustainable practises, in: Nordes 17: Design + Power, 15-17 June 2017, Oslo, 2017.

infas: MiD2017 Tabellenband, Bundesministerium für Verkehr und digitale Infrastruktur, Bonn, available at: http://www.mobilitaet-in-deutschland.de/pdf/MiD2017_

Tabellenband_Deutschland.pdf, last access: 24 November 2018.

Jarass, J. and Heinrichs, D.: New Urban Living and Mobility, Transp. Res. Proced., 1, 142-153, https://doi.org/10.1016/j.trpro.2014.07.015, 2014.

Jeekel, H.: The car-dependent society: a European perspective, Ashgate, Farnham, 2013.

Kaufmann, V.: A territory's hosting potential, Forum Vies Mob., available at: http://en.forumviesmobiles.org/marks/ territorys-hosting-potential-1103 (last access: 21 January 2015), 2012.

Kuckartz, U.: Qualitative Inhaltsanalyse: Methoden, Praxis, Computerunterstützung, 3. überarb. Auflage, Beltz Juventa, Weinheim, 2016.

Kühne, K., Mitra, S. K., and Saphores, J.-D. M.: Without a ride in car country - A comparison of carless households in Germany and California, Transp. Res. Part Policy Pract., 109, 24-40, https://doi.org/10.1016/j.tra.2018.01.021, 2018.

Kuhnimhof, T., Zumkeller, D., and Chlond, B.: Who Made Peak Car, and How? A Breakdown of Trends over Four Decades in Four Countries, Transp. Rev., 33, 325-342, https://doi.org/10.1080/01441647.2013.801928, 2013.

Lagrell, E., Thulin, E., and Vilhelmson, B.: Accessibility strategies beyond the private car: A study of voluntarily carless families with young children in Gothenburg, J. Transp. Geogr., 72, 218227, https://doi.org/10.1016/j.jtrangeo.2018.09.002, 2018.

Mattioli, G.: 'Forced Car Ownership' in the UK and Germany: Socio-Spatial Patterns and Potential Economic Stress Impacts, Soc. Incl., 5, 147-160, https://doi.org/10.17645/si.v5i4.1081, 2017.

Mattioli, G., Lucas, K., and Marsden, G.: Transport poverty and fuel poverty in the UK: From analogy to comparison, Transp. Policy, 59, 93-105, https://doi.org/10.1016/j.tranpol.2017.07.007, 2017.

McLaren, A. T.: Families and transportation: Moving towards multimodality and altermobility?, J. Transp. Geogr., 51, 218-225, https://doi.org/10.1016/j.jtrangeo.2016.01.006, 2016.
Melia, S.: Potential for Carfree Development in the UK, PhD Thesis, University of the West of England, Bristol, available at: http://www.stevemelia.co.uk/Thesis.pdf (last access: 10 December 2014), 2009.

Mitra, S. K. and Saphores, J.-D. M.: Carless in California: Green choice or misery?, J. Transp. Geogr., 65, 1-12, https://doi.org/10.1016/j.jtrangeo.2017.09.016, 2017.

Moser, P. and Stocker, E.: Autofreies Wohnen - Evaluierung der Mustersiedlung in Wien-Floridsdorf, Endbericht, SRZ Stadt- und Regionalforschung GmbH, Wien, 2008.

Müller, H. and Romann, P.: Autofreie Haushalte: ihre Mobilität und die Folgen für Verkehrsplanung und Verkehrspolitik, NFP 41 "Verkehr und Umwelt: Wechselwirkungen Schweiz - Europa", EDMZ, Bern, 1999.

Nieuwenhuijsen, M. J. and Khreis, H.: Car free cities: Pathway to healthy urban living, Environ. Int., 94, 251-262, https://doi.org/10.1016/j.envint.2016.05.032, 2016.

Oakil, A. T. M., Manting, D., and Nijland, H.: Dynamics in car ownership: the role of entry into parenthood, Eur. J. Transp. Infrastruct. Res., 16, 661-673, 2016.

OFS/ARE: Comportement de la population en matière de transports. Résultats du microrecensement mobilité et transports 2015, Office fédéral de la statistique/Office fédéral du développement territorial, Neuchâtel, Berne, 2017.

Ornetzeder, M., Hertwich, E. G., Hubacek, K., Korytarova, K., and Haas, W.: The environmental effect of car-free housing: A case in Vienna, Ecol. Econ., 65, 516-530, https://doi.org/10.1016/j.ecolecon.2007.07.022, 2008.

Ortegon-Sanchez, A., Popan, C., and Tyler, N.: Car-free initiatives from around the world: concepts for moving to future sustainable mobility, in: TRB 96th Annual Meeting Compendium of Papers, Washington, D.C., 2017.

Parodi, O., Beecroft, R., Albiez, M., Quint, A., Seebacher, A., Tamm, K., and Waitz, C.: The ABC of Real-world Lab Methodology - From "Action Research" to "Participation" and Beyond, Trialog, 126/127, 74-84, 2017.

Preisendörfer, P. and Rinn, M.: Haushalte ohne Auto?: eine empirische Untersuchung zum Sozialprofil, zur Lebenslage und zur Mobilität autofreier Haushalte, Leske und Budrich, Leverkusen, 2003.

Prillwitz, J. and Barr, S.: Moving towards sustainability? Mobility styles, attitudes and individual travel behaviour, J. Transp. Geogr., 19, 1590-1600, https://doi.org/10.1016/j.jtrangeo.2011.06.011, 2011.

Rérat, P.: Residential mobility, Mob. Lives Forum, available at: http://en.forumviesmobiles.org/marks/residential-mobility-3204 (last access: 27 November 2018), 2016.

Rérat, P.: A decline in youth licensing: a simple delay or the decreasing popularity of automobility?, Appl. Mobil., 1-21, https://doi.org/10.1080/23800127.2018.1545737, 2018.

Rérat, P. and Lees, L.: Spatial capital, gentrification and mobility: evidence from Swiss core cities, Trans. Inst. Br. Geogr., 36, 126142, https://doi.org/10.1111/j.1475-5661.2010.00404.x, 2011.

Rérat, P., Baehler, D., and Gurtner, M.: Le choix de vivre en villecentre: interactions entre mobilité résidentielle et mobilité quotidienne, Géo-Regards Rev. Neuchâtel, Géographie, 6, 69-82, 2013. 
Reutter, O. and Reutter, U.: Autofreies Leben in der Stadt: autofreie Stadtquartiere im Bestand, Dortmunder Vertrieb für Bau- und Planungsliteratur, Dortmund, 1996.

Rössel, J. and Otte, G.: Lebensstile in der Soziologie, in Lebensstilforschung, edited by: Rössel, J. and Otte, G., VS Verlag, Wiesbaden, 7-34, 2011.

Sattlegger, L. and Rau, H.: Carlessness in a car-centric world: A reconstructive approach to qualitative mobility biographies research, J. Transp. Geogr., 53, 22-31, https://doi.org/10.1016/j.jtrangeo.2016.04.003, 2016.

Scheurer, J.: Urban ecology, innovations in housing policy and the future of cities: towards sustainability in neighbourhood communities, PhD Thesis, Murdoch University, Perth, Australia, 2001.

Schreier, M.: Varianten qualitativer Inhaltsanalyse: Ein Wegweiser im Dickicht der Begrifflichkeiten, Forum Qual. Sozialforschung Forum Qual. Soc. Res., 15, 18, 2014.

Schwartz, S. H.: Value Priorities and Behavior: Applying a Theory of Integrated Value Systems, in: The Psychology of Values: The Ontario Symposium, vol. 8, edited by: Seligman, C., Olson, J. M., and Zanna, M. P., Lawrence Erlbaum, Mahwah, NJ, 1996.
Schwartz, S. H.: European Social Survey Core Questionnaire Development - Chapter 7: A Proposal for Measuring Value Orientations across Nations, European Social Survey, City University London, London, 2001.

Shove, E.: Beyond the ABC: Climate Change Policy and Theories of Social Change, Environ. Plan. Econ. Space, 42, 1273-1285, https://doi.org/10.1068/a42282, 2010.

Statistische Ämter des Bundes und der Länder: Ergebnisse des Zensus 2011, available at: https://ergebnisse.zensus2011.de/ (last access: 28 February 2018), 2014.

Urry, J.: The 'System' of Automobility, Theory Cult. Soc., 21, 25 39, https://doi.org/10.1177/0263276404046059, 2004.

Villeneuve, D.: Living Without a Car A Canada-France Comparative Outlook, PhD Thesis, Ecole Polytechnique Fédérale de Lausanne, Lausanne, 2017.

Vincent-Geslin, S.: Les altermobilités: une mise en pratique des valeurs écologiques?, Norois, 231, 113-124, 2014. 